\title{
Polar Regions (2018)
}

\author{
Stefan Kirchner*
}

Climate change not only has long-term implications ${ }^{1}$ but it already affects communities in the Arctic today and has implications for disaster risk reduction as well: climate change leads to a reduction in sea ice coverage, ${ }^{2}$ which in turn is leading to a boom in polar tourism. This is particularly visible in the case of growing cruise tourism in the Arctic. Throughout human memory, at least part of the sea-ice has been permanent multi-year ice ${ }^{3}$ but today an icefree Arctic Ocean at least during the summer time is becoming a realistic prospect.

The decrease in sea ice and the warming of the Arctic enable a range of human activities at an unprecedented scale, for example resource extraction or tourism. This leads to an increasing human presence in the Arctic and an increasing disaster risk. As the increased presence is not permanent but more of a transient nature (for example in the case of tourists or temporary workers in the mining sector), the local infrastructure is usually not growing at the same pace. This makes disaster responses more difficult. Resilience also has an infrastructure dimension. While, "[f]rom a traditional security viewpoint, the Arctic is a low-intensity region, ${ }^{4}$ safety remains a matter of serious concern in the region. Due to the low population density and the resulting limited Search and Rescue (SAR) infrastructure and long distances, mass emergencies and mass casualty events provide a significant challenge in the Arctic. Increasing tourism, in particular cruise tourism, has made such events more likely. The growing number of visitors and the lack of Search and Rescue (SAR) infrastructure, combined with the continued presence of natural hazards in polar regions, increases the risk of disasters and of disaster response failures. While international disaster law is used to address these issues to some extent, there are still significant gaps which require not only regulation but, more importantly, active implementation of existing norms. These norms are not only those which

* Associate Professor, University of Lapland.

1 Naomi Klein, No is not enough - Defeating the New Shock Politics (Allen Lane 2017) 66.

2 Peter Wadhams, A Farewell to Ice - A Report from the Arctic (Penguin 2017) 83.

3 See Henry Pollack, A World without Ice (Avery 2010) 120.

4 José Miguel Roncero Martín, 'Policies and Strategies for the Arctic: A Review of the Approaches to Human Security in the Arctic' in Kamrul Hossain, José Miguel Roncero Martín and Anna Petrétei (eds), Human and Societal Security in the Circumpolar Arctic (Brill 2018) 19 . 
are explicitly aimed at the reduction of disaster risks but also norms which have existed for a long time, for example as part of the international law of the sea. For example, the 2018 Joint Arctic Search and Rescue Tabletop Exercise and Workshop in Iceland dealt with the scenario of a cruise ship disaster approximately 110 nautical miles west of the island of Jan Mayen. ${ }^{5}$ Bringing together State and non-state actors, ${ }^{6}$ the exercise focused on the role other cruise ships can play in rendering assistance to vessels in emergency situations, a duty which is also enshrined in both customary international law and in the United Nations Convention on the Law of the Sea. Similarly, Norway and the Russian Federation conducted a tabletop exercise involving a ferry disaster. ${ }^{7}$ While a maritime disaster involving a cruise ship in the Arctic can be seen as being on the worst-case end of the spectrum of potential disasters, the limited infrastructure and number of SAR personnel mean that already an accident involving a train or a bus accident can bring local SAR services to their limit. It is therefore fitting that an exercise was conducted in Bíldudalur, Iceland, in May 2018 concerning the simulation of an airplane crash in a rural area. ${ }^{8}$

The relevance of the polar tourism boom has been emphasized in study published by the Finnish Red Cross in 2018:

Mass tourism brings along challenges. The increased number of people put pressure on land, wildlife and water, waste disposal and pollution through increased airplane and ship traffic, the risk of major accidents increases and there might be conflicts between local cultural practices and the recreational activities of the tourists (...). It has been established that there is a missing link between tourism and disaster risk reduction and management as well as frameworks for examining climate change and tourism (...). As tourism increases human presence in the area and people often lack the crucial know-how of the local conditions, it would be very important to build tourism risk reduction patterns and practices. In some cases, unnecessary risks related to tourism are being taken. There

5 Association of Arctic Expedition Cruise Operators, 'Third Joint Arctic SAR TTX 2018 Exercise Report' (1o September 2018) <https://www.aeco.no/events/fourth-joint-arctic-sar-workshopand-ttx-2019/> last accessed (as any subsequent URL) on 15 March 2019, 6.

6 Ibid.

7 Marex, 'Russia and Norway Hold Tabletop Cruise Ship Rescue Exercise' (10 March 2018) <https://www.maritime-executive.com/article/russia-and-norway-hold-tabletop -cruise-ship-rescue-exercise $>$.

8 Finnish Red Cross, 'Red Cross Arctic Disaster Management Study' (1 August 2018), <https:// reliefweb.int/sites/reliefweb.int/files/resources/red_cross_arctic_disaster_management _study.pdf>, $45 \mathrm{ff}$. 
have been cases of cruise ships intentionally travelling close to the ice edge and shorelines to provide best opportunities for wildlife viewing, at the same time increasing the risk of interaction with ice and other haz$\operatorname{ards}(\ldots)^{9}$

While disaster risk reduction in the context of tourism already begins before tourists embark on a journey, the involvement of multiple individual and corporate actors from several countries remains a challenge from the perspective of disaster risk reduction law. A case in point is the growing importance of individual tourism in the Arctic and Sub-Arctic and the increasing demand for rental cars by tourists in locations such as Iceland or Lapland/Sápmi where tourists operating unfamiliar vehicles may meet challenging road conditions, thus increasing the risk of accidents. While polar tourism draws its attractiveness from an element of adventure, the increasing accessibility of e.g. the European high north can mask the actual risks which exist there. In how far law (beyond generally applicable norms such as speed limits) is the best possible tool to address such risks faced by tourists is a question which has to be answered by the domestic legislatures as particular knowledge of the local situation is required for adequate assessments.

In particular in rural areas, the availability of volunteers is essential for mounting an effective disaster response. From a legal perspective, successfully engaging with civil society organizations requires the existence of clear legal frameworks within which volunteers can operate. The cooperation between public actors and civil society organizations and especially the work of volunteers vital to secure sufficient human resources in the event of a disaster. Of particular importance is the work of the national Red Cross societies. With the exception of Sweden, ${ }^{10}$ where the Red Cross is referred to in several legal instruments ${ }^{11}$ and where the national Red Cross society also seeks increased cooperation with public actors, ${ }^{12}$ all national Red Cross societies in the eight Arctic countries enjoy some kind of official status on the national level in the form of a specific law ${ }^{13}$ and have entered into agreements with public authorities. ${ }^{14}$ Not only is the local knowledge of volunteers essential in disaster situations, ${ }^{15}$ also the cooperation between national Red Cross societies and

\begin{tabular}{ll}
\hline 9 & Ibid., 11. \\
10 & Ibid., 19 and 37. \\
11 & Ibid., 19. \\
12 & Ibid., 37. \\
13 & Ibid., 19 ff. \\
14 & Ibid., 37 ff. \\
15 & Ibid., iv.
\end{tabular}


public authorities helps to provide a more complete range of disaster response options. ${ }^{16}$ Clear rules for the cooperation between non-state actors and authorities on different levels of government can contribute to strengthening the involvement of volunteers and thereby to the enhancement of disaster risk response capacities. In particular in the Nordic countries, where a strong role for the State has long been accepted and where public private partnerships are still more of an emerging concept than in many other places, the legal certainty gained by such agreements with the authorities or through law-making on the national level, can strengthen the sustainability of the work of nonstate actors such as the Red Cross. The need for legal certainty also applies to ad hoc volunteers, i.e. persons who spontaneously help in an emergency situation. ${ }^{17}$ This includes legal protections in case of injuries or other damages sustained while volunteering and clear liability rules regarding potential damages caused by volunteers when trying to help. In particular in regions where the crossing of international borders is a common occurrence, such as in the European high north, a harmonization of such rules is desirable. This tort law dimension of disaster risk reduction law appears to require further development and academic research.

Overall, 2018 saw limited legal developments but a greater emphasis on practical cooperation across borders. International legal frameworks already exist and are being implemented continuously. The Arctic Council continues to play a key role in this regard, for example through the Arctic Search and Rescue Agreement (Arctic SAR Agreement), ${ }^{18}$ which has been created under its auspices. In the context of the Arctic Council, the work of the Emergency Prevention, Preparedness and Response (EPPR) working group, which now consists of two new expert groups which are concentrating on Search and Rescue as well as on Marine Environmental Response, essentially mirroring the Arctic SAR Agreement and the Agreement on Cooperation on Marine Oil Pollution Preparedness and Response in the Arctic (MOSPA)..$^{19}$ The efforts of the EPPR working group. which is organizing workshops and exercises, ${ }^{20}$ are particularly important as the myriad of State and non-state actors involved in

\footnotetext{
16 Ibid., iv.

17 See ibid., 25 .

18 Agreement on Cooperation on aeronautical and maritime search and rescue in the Arctic, 12 May 2011.

19 Agreement on Cooperation on Marine Oil Pollution Preparedness and Response in the Arctic, 15 May 2013.

20 Arctic Council, 'Emergency Prevention, Preparedness and Response (EPPR)' (13 October 2017) <https://arctic-council.org/index.php/en/about-us/working-groups/eppr>.
} 
disaster prevention and mitigation, the absence of clear data, ${ }^{21}$ etc. make it difficult to adequately assess the current level of cross-border cooperation. Also the Red Cross Arctic Disaster Management project run by the Finnish Red Cross $^{22}$ provides an important contribution to better understanding of the available disaster response capacities in the Arctic.

The governance of disaster risk and disaster risk reduction law in the Arctic have gained more attention from academia in $2018 .^{23}$ This is especially the case with regard to maritime safety in the Arctic, ${ }^{24}$ which received more attention in the wake of the entry into force of the Polar Code on 1 January 2017. The increasing attention given especially to the Arctic, and to a certain degree also to Antarctica, is leading to more awareness of the particular challenges concerning the reduction of disaster risks in polar regions. A particularly noteworthy approach to DRR is shown by a special issue of the International Journal of Disaster Risk Reduction which was published in December 2018: ecosystembased disaster risk reduction (Eco-DRR) and ecosystem-based approaches to climate adaptation $(\mathrm{EbA})^{25}$ have the potential to contribute to the development of tailored solutions rather than "one size fits all"-approaches to DRR which might prove particularly valuable in the extreme polar environments. As highlighted by Tiyanti and Chu, governance of Eco-DRR and EbA continues to provide open questions which require further research. ${ }^{26}$

Unlike in the case of the Arctic, large parts of which fall either under the sovereignty or at least the sovereign rights (as in the case of Exclusive Economic

21 See Anne Stauffer, Justin Theal, and Colin Foard, 'Natural Disaster Mitigation Spending Not Comprehensively Tracked' (20 September 2018) <https://www.pewtrusts.org/en/ research-and-analysis/issue-briefs/2018/og/natural-disaster-mitigation-spending--not -comprehensively-tracked>.

22 See Finnish Red Cross (n. 8).

23 E.g. Kristian Cedervall Lauta, Morten Thanning Vendelø, Birgitte Refslund Sørensen and Rasmus Dahlberg, 'Conceptualizing cold disasters: Disaster risk governance at the Arctic edge', (2018) 31 International Journal of Disaster Risk Reduction, 1276; Kristian Cedervall Lauta and Adriaan Perrels, 'Nordic disaster risk reduction: Shared spirit, different designs', (2018) 31 International Journal of Disaster Risk Reduction, 1262.

24 E.g. Joan Mileski, Amir Gharehgozli, Lawrence Ghoram and Ryan Swaney, 'Cooperation in developing a disaster prevention and response plan for Arctic shipping', (2018) 92 Marine Policy, 131.

25 See e.g. Alistair McVittie, Lorna Cole, Anita Wreford, Alessandra Sgobbi and Beatriz Yordi, 'Ecosystem-based solutions for disaster risk reduction: Lessons from European applications of ecosystem-based adaptation measures', (2018) 32 International Journal of Disaster Risk Reduction, 42.

26 Annisa Tiyanti and Eric Chu, 'A survey of governance approaches to ecosystem-based disaster risk reduction: Current gaps and future directions', (2018) 32 International Journal of Disaster Risk Reduction, 11. 
Zones (EEZs) ${ }^{27}$ and Continental Shelves ${ }^{28}$ ) of nation states, ${ }^{29}$ no nation State has sovereignty over Antarctica ${ }^{30}$ and Article IV of the 1959 Antarctic Treaty ${ }^{31}$ has been interpreted as not allowing for the creation of Exclusive Economic Zones off the coast of Antarctica ${ }^{32}$ (although Australia claims an EEZ off the coast of Antarctica). Independently of the question of the permissibility of EEZs, states in the region have created Search and Rescue Regions for which coastal states of the Southern Ocean are undertaking the responsibility to provide maritime SAR services.

In terms of reducing the risk of disasters, the self-regulation by the members of the International Association of Antarctic Tour Operators (IAATO) continues to play an important role due the absence of local nation states in Antarctica. With the exception of two Japanese vessels, all cruise vessels operating off the coast of Antarctica are represented by IAAто. ${ }^{33}$ IAATO offers certifications for field staff as well as other online assessment tools, a Field Operations Manual as well as an app for smartphones, which is aimed both at professionals working in and visitors to Antarctica. ${ }^{34}$ Among the regulatory efforts undertaken by the IAATO is the ban on the operation of the recreational use of aerial drones in coastal areas which are home to wildlife. ${ }^{35}$ Also the Antarctic Treaty Consultative Meeting adopted a resolution on environmental guidelines for the operation of uncrewed aircraft. ${ }^{36}$ Neither measure will prevent the use of drones for scientific or rescue purposes.

While the two polar regions differ both from a legal perspective and also in the practice of disaster response operations, international legal frameworks

27 United Nations Convention for the Law of the Sea, 10 December 1982, art. $5^{6}$ para. 1(a).

28 Ibid., art. 77, para. 1.

29 See Karen N. Scott and David L. Vander Zwaag, 'Polar Oceans and Law of the Sea' in Donald R. Rothwell, Alex G. Oude Elferink, Karen N. Scott and Tim Stephens (eds), The Oxford Handbook of the Law of the Sea (OuP 2017) 724, $729 \mathrm{ff}$.

30 Wolff Heintschel von Heinegg, Friedliche Nutzung, ,Seekriegs- und Neutralitätsrecht, Friedenssicherung' in Wolfgang Graf Vizthum (ed), Handbuch des Seerechts (C.H. Beck 2006) 491, 532.

$31 \quad$ Antarctic Treaty, 1 December 1959.

32 Robin R. Churchill and A. Vaughan Lowe, The law of the sea (Manchester University Press 1999) 165 .

33 XLI Antarctic Treaty Consultative Meeting, Report of the International Association of Antarctica Tour Operators 2017-18 (12 May 2018) <https://iaato.org/documents/10157/ 2398215/Report+of+IAATO+IPo7o/f5cd4c64-2a5d-41b4-b251-491c871d2bec >, 3 .

34 Ibid.

35 Ibid., 5 .

36 Final Report of the Forty-first Antarctic Treaty Consultative Meeting, Resolution 4 (2018), Environmental Guidelines for operation of Remotely Piloted Aircraft Systems (RPAS) in Antarctica (2018) <https://www.ats.aq/documents/ATCM41/fr/ATCM41_fro11_e.pdf>, 199. 
exist which allow for international cooperation to prevent and react to disasters. Fortunately, the small number of incidents means that it remains to be seen how existing international agreements can be implemented in practice. It has to be noted, however, that regulatory gaps continue to exist, for example in relation to fishing vessels, which are not covered by the scope of the Polar Code. From a technical perspective, a harmonization of technical standards for SAR operations for the purpose of securing interoperability between different SAR actors might be desirable in the future as well, as would be the possibility to provide human resources and materials ${ }^{37}$ across borders if needed which in turn would raise new legal questions.

37 On the importance of logistics in Arctic disaster situations see e.g. Finnish Red Cross (n. 8) 25 . 